\title{
ASSESSMENT OF EDUCATION POLICY THRUST OF THE NATIONAL ECONOMIC EMPOWERMENT AND DEVELOPMENT STRATEGY (NEEDS) IN NIGERIA
}

Isaac Olakanmi Abimbola, Esther Ore Omosewo, Johnson Enero Upahi University of Ilorin, Ilorin, Nigeria

E-mail: johnsonenero@yahoo.com, oresewo@yahoo.co.uk, upahi.je@unilorin.edu.ng

\begin{abstract}
The National Economic Empowerment and Development Strategy (NEEDS) is Nigeria's plan for prosperity. The plan focuses on four key strategies: reorienting values, reducing poverty, creating wealth and generating employment. In realizing the plan, education is recognized as the vital transformational tool and a formidable instrument for any socioeconomic empowerment. Policy frameworks for education were developed to propel and sustain the NEEDS initiative. The NEEDS set six goals (with targets) for education, and each of the goals is keyed to each of the policy thrust. This study, therefore, attempted to assess the extent to which the targets of NEEDS for education are implemented. A structured questionnaire was developed to elicit 250 university lecturers'views on the extent of implementation of the education policy thrust of the NEEDS. It was found that, the targets of each of the goals of the plan that were originally designed to be a medium-term development strategy; spanning year (2004-2007) have not been fully realized 10 years after its inception. Conclusion was drawn and recommendations were made, among which are: the NEEDS planners and operators should set specific, realizable targets and time framework of human development, for students to become self-sufficient in the areas of basic needs through skills acquisition and job creation.
\end{abstract}

Key words: the National Economic Empowerment and Development Strategy, targets and education.

\section{Introduction}

Education is the essential foundation of any thriving and innovative society, and as such, the quality of education in a society is no less important for economic development. As competition among economies becomes more intense, the importance of education as the key to future successes, intensifies. It has been found that the major cause of differences between the economies of developed and developing countries lies in the quality and quantity of education offered. The quality of education offered in developed countries, is the kind that empowers recipients' to be creators of jobs rather than job-seekers, and also because basic education is mandatory, hence, the high literacy level in such countries.

Education equips individuals with the necessary knowledge, skills, and attitudes that will enable them to explore their world, manipulate it for their survival and establish themselves within the society. Potentials deposited in such individuals are harnessed through education, as they acquire training and knowledge in a profession, from where they can earn a living. As observed by Adedokun (2011), education more often than not, holds the key to other conditions such as taking proper decisions about living and skills that can assist an individual economically, politically and socially in a society. Anugwom (2009) also opined that education is the main tool for imparting skills and attitudes relevant to the contribution of the individual to the 
Isaac Olakanmi ABIMBOLA, Esther Ore OMOSEWO, Johnson Enero UPAHI. Assessment of Education Policy Thrust of the National Economic Empowerment and Development Strategy (Needs) in Nigeria

BLEMS

OF EDUCATION

IN THE $21^{\text {st }}$ CENTURY

Volume 60, 2014

development of the society. It is a key every individual should possess to make a significant contribution to personal and national development. In the opinion of Imogie (2002), the prosperity of a country depends not only on the abundance of its revenue, nor on the strength of its fortifications, but on the number of its citizens that are enlightened through education.

The Nigerian educational system has been bedeviled with quite a lot of challenges that are systemic. Apparently, the delivery of education in Nigeria has suffered from years of neglect, compounded by inadequate attention to policy frameworks within the sector. Abimbola (2013) posited that policy inconsistency is one of the major characteristics of educational policies in Nigeria. He further mentioned that these policy inconsistencies are not unconnected with the fact that, within the last fourteen years that a civilian rule was re-introduced in Nigeria, there have been twelve Ministers of Education with varying policies.

Findings from an ongoing educational sector analysis confirm the poor state of education in Nigeria. The national literacy rate is currently 57 percent, some 49 percent of the teaching force is unqualified, and there are acute shortages of infrastructure and facilities at all levels (Adedokun, 2011). Access to basic education is inhibited by gender issues and socio-cultural beliefs and practices, among other factors. Wide disparities persist in educational standards and learning achievements (Anugwom, 2009). The system emphasizes theoretical knowledge at the expense of technical, vocational, and entrepreneurial education. School curricula need urgent review to make them relevant and practice-oriented.

In the face of these teeming challenges, the Federal Government of Nigeria launched its medium-term development strategy entitled "National Economic Empowerment and Development Strategy (NEEDS)". The 2010 Paris Declaration target on Aid Effectiveness and the 2001 Kuru Declaration (as cited in National Planning Commission, 2005) embodies the vision of NEEDS for Nigeria:

To build a truly great African democratic country, politically united, integrated and stable, economically prosperous, socially organized, with equal opportunity for all, and responsibility from all, to become the catalyst of (African) Renaissance, and making adequate all-embracing contributions, subregionally, regionally, and globally (p. viii).

In the pursuit of the NEEDS, the Federal Government of Nigeria recognized education as the vital transformational tool and a formidable instrument for socioeconomic empowerment, as no nation is known to have developed without quantitative and qualitative education (NPC, 2005).

\section{A Brief History of Economic Reforms in Nigeria}

There have been radical and conscious efforts by the government to implement a series of economic reforms that would touch all the facets of the economy to be in tune with the policies of this era of globalization. In Nigeria, the government has come up with various economic reforms to turn the economy around and has called it different names, which include Structural Adjustment Programme (SAP), removal of subsidies in agriculture, deregulation of the financial sector, privatization programme, deregulation of upstream and downstream oil sector (Bamiduro \& Babatunde, 2009) and a decade ago, the National Economic Empowerment And Development Strategy (NEEDS) - which is the focus of this paper.

The Federal Government of Nigeria launched its medium-term development strategy or plan entitled National Economic Empowerment and Development Strategy (NEEDS) in May, 2004 to achieve and boost the Millennium Development Goals (MDGs). The MDGs recognizes that education is associated with many development outcomes and interacts with other factors 
to contribute to the achievement of the related MDGs (UNESCO \& UNICEF, 2013). Though, the NEEDS is a medium-term economic reform programme, its formulation has been made consistent with both short-term realities and long-term imperatives, that derive from the country's long-term goals of poverty reduction, wealth creation, employment generation and value reorientation. The four key strategies to achieve the goals are: reforming the way government and its institutions work, development of the private sector, implementing a social charter for the people and re-orientation of the people with an enduring new value system.

The National Economic Empowerment and Development Strategy (NEEDS) also recognize education as the vital transformational tool and a formidable instrument for socioeconomic empowerment. Education is universally acknowledged as the vehicle of development in any society. It is equally a veritable catalyst for the development of an individual. Indeed, literacy, which is a core element in education, is the main focus and the starting point of all formal and non-formal learning. It is a means for the attainment of the full social and economic potential of the individual or the State. In a wider perspective, it is a channel of developing intellectual capacity of the population to understand, analyze and appreciate problem and the environment. In fact, Education is the pivot to acquire physical and mental skills necessary for the development of the individual and the society.

The education sector has responsibility for producing and supplying the personnel required to propel and sustain the NEEDS initiative. The goals of wealth creation, employment generation, poverty reduction, and value reorientation can be effectively pursued, attained, and sustained only through an efficient, relevant and functional education system. Education is critical to meeting the goals set by NEEDS. It is also a sector that the initiative seeks to reform.

\section{Policy Framework and Strategies of the National Economic Empowerment and Development Strategy (NEEDS) for Education}

The policy thrust is to improve the quality, relevance and access to education and enhance its contribution to individuals and consequently, on national development. The NEEDS aimed at improving the efficiency and productivity of educational personnel staff through training and provision of adequate incentives. Emphasis will be placed on science, technology, vocational, and entrepreneurial and computer education. It will encourage active participation of the private sector, non-governmental organizations, individuals, communities and companies in educational development.

The overall policy thrust of NEEDS in education is to:

- Provide unhindered access to compulsory universal basic education to all citizens as a bridge to the future socioeconomic transformation of Nigerian society.

- Establish and maintain enhanced quality and standards through relevant, competency-based curricula and effective quality control at all levels.

- Enhance the efficiency, resourcefulness, and competence of teachers and other educational personnel through training, capacity building, and motivation.

- Strengthen Nigeria's technological and scientific base by revamping technical, vocational, and entrepreneurial education and making optimal use of information and communication technologies to meet the economy's manpower needs.

- Provide an enabling environment and stimulate the active participation of the private sector, civil society organizations, communities, and development partners in the educational development (NPC, 2005). 
Isaac Olakanmi ABIMBOLA, Esther Ore OMOSEWO, Johnson Enero UPAHI. Assessment of Education Policy Thrust of the National Economic Empowerment and Development Strategy (Needs) in Nigeria

OF EDUCAT

IN THE $21^{\text {st }}$ CENTURY

Volume 60, 2014

The National Economic Empowerment and Development Strategy (NEEDS) set six goals for education. A goal is keyed to each of the policy thrust of NEEDS in education. The first is to ensure and sustain unfettered access to education for the total development of the individual, the need to improve the quality of education at all levels, and to use education as a tool for improving the quality of life through skill acquisition and job creation for poverty reduction. The other goals are to ensure periodic review and effective implementation of the curriculum at the secondary level to meet the requirements of higher education and the world of work; mobilize and develop partnerships with the private sector and local communities to support and fund education; and to promote information and communication technology capabilities at all levels of education.

Strategies for achieving the goals include the following:

- Complete and harmonize all on-going educational planning programmes and initiatives in the Ministry of Education and its agencies;

- Make learning and teaching environments child and teacher friendly;

- Train and retrain teachers, through formal and distance learning programmes;

- Review curricula at all levels for relevance, and make them competency based to meet global challenges and the needs of the job market;

- Provide adult and youth vocational centres with materials and equipment for functional literacy and the acquisition of occupational skills;

- Establish effective partnership and collaboration with the organized private sector and the informal sector;

- Produce textbooks and other instructional materials to reflect the curricula;

- Integrate local craftspeople in curricular delivery to accelerate the number of craftspeople and improve access to their products;

- Involve parents and community leaders in the planning and management of schools in their communities;

- Set guidelines on private sector involvement in education and monitor its implementation.

- Incorporate computer literacy in primary and secondary school curricula;

- Develop and produce curricula for teaching computer education in secondary schools;

- Provide secondary and tertiary institutions with information and communication technology equipment and facilities (NPC, 2005).

Under NEEDS, the government also recognizes the critical importance of tertiary institutions for developing high-quality human resources, especially in an increasingly technologydriven world economy. The government also recognizes the challenges facing these institutions, challenges that include inadequate funding and facilities, curricula that are inadequate to meet the challenges of nation building, inadequate and inappropriate staffing (especially among the lecturers), cultism, low morals and academic standards, among students. Higher institutions in Nigeria currently depend almost exclusively on government subsidies. The bulk of federal gov- 
ernment spending on education goes to tertiary institutions; state governments spend at least 20 percent of their budget on education, mostly primary and secondary education. The almost total dependence on the government for funding higher education is neither practical nor sustainable. There is therefore a need for fundamental reforms of the higher education system.

The strategy proposed for reform includes the following:

- Strictly adhere to the provisions of the University Autonomy Act;

- Diversify funding by attracting private sector funding and considering more appropriate pricing of facilities and services (including hostel accommodation);

- Update and restructure curricula to meet the demands of the national economy, and mainstream science and technology, especially information and communication technology;

- Establish effective monitoring of public and private universities to ensure strict adherence to standards;

- Develop innovative approaches to ensure continuing retooling and capacity building of lecturers so that they operate at the cutting edge of their disciplines;

- Increasingly move towards a decentralized and competitive wage bargaining system, which promotes a performance-based reward system.

The NEEDS initiative advocates greater involvement and participation by the private sector in educational development. An enabling environment will be created to increase private sector participation. Establishment of good-quality privately owned educational institutions at all levels will be encouraged to ensure that gaps in the provision of education are filled. Efforts will be made to achieve 100 percent compliance in paying the 2 percent corporate profit tax that funds education. Linkages between educational institutions and the private sector will be strengthened to ensure the appropriate interface with the world of work.

The NEEDS established government economic programme and poverty reduction strategy to boost and achieve the United Nations (UN) - sponsored Millennium Development Goals (MDGs) - which will end by 2015. Under the programme, which covers the years from 2000 to 2015, the National Economic Empowerment and Development Strategy constitute a balanced approach to meeting the Millennium Development Goals, combining strategies for poverty reduction, growth and economic diversification outside of the oil sector.

In an update released in 2010, the UN found that Nigeria was making progress toward achieving several goals but was falling short on others. Specifically, Nigeria had advanced efforts to provide universal primary education, protect the environment, and develop a global development partnership. However, the country lagged behind on a number of other goals (UNDP, 2010).

Since the NEEDS as a medium-term strategy was intended to complement and boost the achievement of the MDGs, therefore, there is a need to assess the extent of implementation of the goals and targets of the National Economic Empowerment and Development Strategy with respect to education.

\section{Purpose of the Study}

The main purpose of this study was to assess lecturers' views on the extent of implementation of the set targets of the Education Policy Thrust of the National Economic Empowerment and Development Strategy (NEEDS), a decade after its inception. 
Isaac Olakanmi ABIMBOLA, Esther Ore OMOSEWO, Johnson Enero UPAHI. Assessment of Education Policy Thrust of the National Economic Empowerment and Development Strategy (Needs) in Nigeria

OF EDUCATION

IN THE $21^{\text {st }}$ CENTURY

Volume 60, 2014

Research Questions

The following research questions were generated for the purpose of finding out from the educators what their views were concerning the achievement of the goals of the NEEDS:

1. Do pupils and students of all school levels have an unfettered access to education for their development?

2. Is there an improved quality of education at all levels?

3. Have students of all levels acquired basic life, technical and entrepreneurial skills to live meaningfully?

4. Do the periodic review and implementation of the secondary school curriculum meet the requirements of higher education and the world of work?

5. Is there an improved partnership among private sectors and local communities with respect to support and fund for education?

6. Is there an improved level of ICT capabilities among students, their teachers and university lecturers?

\section{Methodology of Research}

\section{Research Design}

A descriptive research of the survey type was employed in this study. The study data were collected from a convenient sample of individuals within a specific population. In this study, data were obtained from university lecturers within the Faculties of Education at University of Ilorin, Adekunle Ajasin University, Akungba-Akoko and Ekiti State University, AdoEkiti, all in Nigeria.

\section{Sample for the Study}

The study sample consisted of 250 university lecturers purposively selected from the Faculties of Education in three Nigerian universities; as they were considered as better informed on the achievement of the goals of the NEEDS set for education. Stratified and purposive sampling techniques were used in selecting 3 universities in the South-West and one university from North-Central, Nigeria. We assumed that educators monitor developments in education at all levels, and so, they are qualified to express opinions about such developments.

Table 1 presents the number and percentages of lecturers who participated against two demographic variables: gender and age-group.

Table 1. Number and percentages of responses against gender and age-group.

\begin{tabular}{llll}
\hline Variable & Label & Number of Respondents & $\%$ \\
\hline \multirow{2}{*}{ Gender } & Male & 183 & 73 \\
\cline { 2 - 4 } & Female & 67 & 27 \\
\hline \multirow{3}{*}{ Age-group } & $26-34$ & 37 & 15 \\
\cline { 2 - 4 } & $35-44$ & 113 & 45 \\
\hline Total & $45+$ & 100 & 40 \\
\hline
\end{tabular}




\section{Research Instrument}

The instrument for data collection was a structured questionnaire developed to elicit university lecturers' views of the implementation level of targets of the National Economic Empowerment and Development Strategy (NEEDS) with respect to education. The instrument used for the study was a questionnaire tagged Education Policy Thrust of the National Economic Empowerment and Development Strategy Questionnaire (EPTNEEDSQ). Section A of the instrument dealt with demographic information of the respondents while section $B$ is the main instrument that elicited information on the level of implementation of the goals set for education and key targets of the goals. The instrument was face validated by three experts, two in the Department of Science Education and a Ph. D. student in Department of Statistics, all from University of Ilorin, Nigeria. The experts looked at the items in terms of clarity of language, instrument's appropriateness to the purpose of the study and the adequacy of items in addressing the problem of the study. The experts' advice and corrections were implemented while modifying the final draft of the instrument.

\section{Procedure for Data Collection}

The instrument for the research was directly administered to the lecturers with the assistance of research assistants. All the data collected were carefully coded and collated. The data collected were analyzed using descriptive statistics involving frequency count, the percentage and chi square.

\section{Results of Research}

Research Question 1: Do pupils and students of all school levels have an unfettered access to education for their development?

Table 2 presents the data on lecturers' responses to the items on the questionnaire. The table also contains male and female lecturers' responses and chi-square analyses of their responses on each of the items. The significant values of each of the targeted items in Table 2 are all greater than 0.05 . This implies that the majority of the lecturers disagreed with the indices of unfettered access to education for the development of pupils and students at all school levels. This result further reveals that male and female lecturers are of the view that pupils and students do not have unfettered access to education for their development. It is, therefore, the view of male and female lecturers that the target goal of ensuring and sustaining unfettered access to education for the total development of the individual is yet to be achieved. 
Isaac Olakanmi ABIMBOLA, Esther Ore OMOSEWO, Johnson Enero UPAHI. Assessment of Education Policy Thrust of the National Economic Empowerment and Development Strategy (Needs) in Nigeria

PROBLEMS

OF EDUCATION

IN THE $21^{\text {st }}$ CENTURY

Volume 60,2014

Table 2. Chi-square analysis of the responses of male and female lecturers on contents pertaining to pupils and students of all school levels having an unfettered access to education for their development.

\begin{tabular}{|c|c|c|c|c|c|c|c|}
\hline \multirow{2}{*}{ Target Content } & \multirow{2}{*}{ Response } & \multicolumn{2}{|l|}{ Gender } & \multirow{2}{*}{ Total } & & \multirow{2}{*}{ df } & \multirow{2}{*}{$p$} \\
\hline & & Male & Female & & & & \\
\hline \multirow{2}{*}{$\begin{array}{l}\text { The percentage of primary school who } \\
\text { have acquired functional literacy and } \\
\text { numeracy has increased to } 100 \text { percent }\end{array}$} & Agree & $5(3.7)$ & $0(1.3)$ & 5 & \multirow[b]{2}{*}{1.868} & \multirow{2}{*}{1} & \multirow{2}{*}{$0.172^{n s}$} \\
\hline & Disagree & $178(179.3)$ & $67(65.7)$ & 245 & & & \\
\hline \multirow{2}{*}{$\begin{array}{l}\text { The percentage of junior secondary } \\
\text { school graduates who go on to senior } \\
\text { secondary school has increased to } 50 \\
\text { percent }\end{array}$} & Agree & $125(128.8)$ & $51(47.2)$ & 176 & \multirow[b]{2}{*}{1.437} & \multirow[b]{2}{*}{1} & \multirow[b]{2}{*}{$0.231^{n}$} \\
\hline & Disagree & $58(54.2)$ & 16 (19.8) & 74 & & & \\
\hline \multirow{2}{*}{$\begin{array}{l}\text { The percentage of senior secondary/ } \\
\text { technical school graduates who go to } \\
\text { tertiary institutions has increased to } 20 \\
\text { percent }\end{array}$} & Agree & $140(142.0)$ & $54(52.0)$ & 194 & \multirow[b]{2}{*}{0.473} & \multirow[b]{2}{*}{1} & \multirow[b]{2}{*}{$0.492^{n}$} \\
\hline & Disagree & $43(41.0)$ & $13(15.0)$ & 56 & & & \\
\hline \multirow{2}{*}{$\begin{array}{l}\text { The adult literacy rate has increased to } \\
65 \text { percent }\end{array}$} & Agree & $8(8.1)$ & $3(2.9)$ & 11 & \multirow{2}{*}{0.001} & \multirow{2}{*}{1} & \multirow{2}{*}{$0.971^{n s}$} \\
\hline & Disagree & $175(174.9)$ & $64(64.1)$ & 239 & & & \\
\hline \multirow{2}{*}{$\begin{array}{l}\text { The number of cases of examination } \\
\text { malpractice in education institutions } \\
\text { has reduced by } 40 \text { percent }\end{array}$} & Agree & $13(14.6)$ & $7(5.4)$ & 20 & \multirow{2}{*}{0.745} & \multirow{2}{*}{1} & \multirow{2}{*}{$0.388^{\text {ns }}$} \\
\hline & Disagree & $170(168.4)$ & $60(61.6)$ & 230 & & & \\
\hline \multirow{2}{*}{$\begin{array}{l}\text { The number of cases of cultism in } \\
\text { educational institutions has reduced by } \\
90 \text { percent }\end{array}$} & Agree & $11(11.7)$ & $5(4.3)$ & 16 & \multirow[b]{2}{*}{0.173} & \multirow[b]{2}{*}{1} & \multirow[b]{2}{*}{$0.678^{n s}$} \\
\hline & Disagree & $172(171.3)$ & $62(62.7)$ & 234 & & & \\
\hline \multirow{2}{*}{$\begin{array}{l}\text { Ninety percent of primary and } \\
\text { secondary schools, have established } \\
\text { sustainable programmes of physical } \\
\text { development }\end{array}$} & Agree & $6(8.1)$ & $5(2.9)$ & 11 & \multirow[b]{2}{*}{2.041} & \multirow[b]{2}{*}{1} & \multirow[b]{2}{*}{$0.153^{\text {ns }}$} \\
\hline & Disagree & $177(174.9)$ & $62(64.1)$ & 239 & & & \\
\hline \multirow{2}{*}{$\begin{array}{l}\text { All tertiary institutions have established } \\
\text { sustainable programmes of physical } \\
\text { development }\end{array}$} & Agree & $7(7.3)$ & $3(2.7)$ & 10 & & & \\
\hline & Disagree & $176(175.7)$ & $64(64.3)$ & 240 & 0.054 & 1 & $0.816^{n s}$ \\
\hline Overall responses to contents pertain- & Agree & $39(40.3)$ & $16(14.7)$ & 55 & & & \\
\hline $\begin{array}{l}\text { levels having an unfettered } \\
\text { access to education for their develop- } \\
\text { ment }\end{array}$ & Disagree & $144(142.7)$ & $51(52.3)$ & 195 & 0.892 & 1 & $0.345^{n s}$ \\
\hline TOTAL (N) & & 183 & 67 & 250 & & & \\
\hline
\end{tabular}

Note. $p \geq 0.05$ (ns, not significant). The expected frequencies appear in parentheses beside agree and disagree responses

Table 3 presents the data on lecturers' age-group responses to items pertaining to access to education for development. The significant values in Table 3 are all greater than 0.05 , which implies that the views of lecturers in the age-groups on each items and the overall item pertaining the achievement of the target that pupils and students of all school levels having an unfettered access to education for their development do not vary significantly. 
Table 3. Chi-square analysis of the responses of lecturers' age-groups on contents pertaining to pupils and students of all school levels having an unfettered access to education for their development.

PROBLEMS

OF EDUCATION

IN THE $21^{\text {st }}$ CENTURY

Volume 60, 2014

\begin{tabular}{|c|c|c|c|c|c|c|c|c|}
\hline \multirow{2}{*}{ Target Content } & \multirow{2}{*}{ Response } & \multicolumn{3}{|c|}{ Age-group } & \multirow{2}{*}{ Total } & & \multirow{2}{*}{ df } & \multirow{2}{*}{$\mathrm{p}$} \\
\hline & & $26-34$ & $35-44$ & $45+$ & & & & \\
\hline \multirow{2}{*}{$\begin{array}{l}\text { The percentage of primary } \\
\text { school who have acquired } \\
\text { functional literacy and } \\
\text { numeracy has increased to } \\
100 \text { percent }\end{array}$} & Agree & $1(0.7)$ & $2(2.3)$ & $2(2.0)$ & 5 & & & \\
\hline & Disagree & $36(36.3)$ & $111(110.7)$ & $98(98.0)$ & 245 & 0.124 & 2 & $0.940^{\text {ns }}$ \\
\hline \multirow{2}{*}{$\begin{array}{l}\text { The percentage of junior } \\
\text { secondary school gradu- } \\
\text { ates who go on to senior } \\
\text { secondary school/technical } \\
\text { school has increased to } 50 \\
\text { percent }\end{array}$} & Agree & $26(26.0)$ & $80(79.6)$ & $70(70.4)$ & 176 & & & \\
\hline & Disagree & $11(11.0)$ & $33(33.4)$ & $30(29.6)$ & 74 & 0.017 & 2 & $0.992^{\text {ns }}$ \\
\hline \multirow{2}{*}{$\begin{array}{l}\text { The percentage of senior } \\
\text { secondary/technical school } \\
\text { graduates who go to tertiary } \\
\text { institutions has increased to } \\
20 \text { percent }\end{array}$} & Agree & $29(28.7)$ & $87(87.7)$ & $78(77.6)$ & 194 & & & \\
\hline & Disagree & $8(8.3)$ & $26(25.3)$ & $22(22.4)$ & 56 & 0.046 & 2 & $0.977^{\text {ns }}$ \\
\hline \multirow{2}{*}{$\begin{array}{l}\text { The adult literacy rate has } \\
\text { increased to } 65 \text { percent }\end{array}$} & Agree & $2(1.6)$ & $5(5.0)$ & $4(4.4)$ & 11 & 0127 & 2 & $0938 n$ \\
\hline & Disagree & $35(35.4)$ & $108(108.0)$ & $96(95.6)$ & 239 & 0.121 & 2 & $0.938^{100}$ \\
\hline \multirow{2}{*}{$\begin{array}{l}\text { The number of cases of } \\
\text { examination malpractice in } \\
\text { education institutions has } \\
\text { reduced by } 40 \text { percent }\end{array}$} & Agree & $4(3.0)$ & $7(9.0)$ & $9(8.0)$ & 20 & & & \\
\hline & Disagree & $33(34.0)$ & $106(104.0)$ & $91(92.0)$ & 230 & 1.033 & 2 & $0.596^{\text {ns }}$ \\
\hline \multirow{2}{*}{$\begin{array}{l}\text { The number of cases of } \\
\text { cultism in educational } \\
\text { institutions has reduced by } \\
90 \text { percent }\end{array}$} & Agree & $4(2.4)$ & $7(7.2)$ & $5(6.4)$ & 16 & & & \\
\hline & Disagree & $33(34.6)$ & $106(105.8)$ & $95(93.6)$ & 234 & 1.537 & 2 & $0.464^{\text {ns }}$ \\
\hline \multirow{2}{*}{$\begin{array}{l}\text { Ninety percent of primary } \\
\text { and secondary schools, } \\
\text { have established sustain- } \\
\text { able programmes of physi- } \\
\text { cal development }\end{array}$} & Agree & $0(1.6)$ & $7(5.0)$ & $4(4.4)$ & 11 & & & \\
\hline & Disagree & $37(35.4)$ & $106(108.0)$ & $96(95.6)$ & 239 & 2.606 & 2 & $0.272^{\text {ns }}$ \\
\hline \multirow{2}{*}{$\begin{array}{l}\text { All tertiary institutions have } \\
\text { established sustainable } \\
\text { programmes of physical } \\
\text { development }\end{array}$} & Agree & $1(1.5)$ & $6(4.5)$ & $3(4.0)$ & 10 & & & \\
\hline & Disagree & $36(35.5)$ & $107(108.5)$ & $97(96.0)$ & 240 & 0.927 & 2 & $0.629^{\text {ns }}$ \\
\hline \multirow{2}{*}{$\begin{array}{l}\text { Overall responses to con- } \\
\text { tents pertaining to pupils } \\
\text { and students of all school } \\
\text { levels having an unfettered } \\
\text { access to education for } \\
\text { their development }\end{array}$} & Agree & $8(8.1)$ & $25(24.9)$ & $22(22.0)$ & 55 & & & \\
\hline & Disagree & $29(28.9)$ & $88(88.1)$ & $78(78.0)$ & 195 & 0.415 & 2 & $0.813^{\text {ns }}$ \\
\hline TOTAL (N) & & 37 & 113 & 100 & 250 & & & \\
\hline
\end{tabular}

Note. $p \geq 0.05$ (ns, not significant). The expected frequencies appear in parentheses beside agree and disagree responses 
Isaac Olakanmi ABIMBOLA, Esther Ore OMOSEWO, Johnson Enero UPAHI. Assessment of Education Policy Thrust of the National Economic Empowerment and Development Strategy (Needs) in Nigeria

PROBLEMS

OF EDUCATION

IN THE $21^{\text {st }}$ CENTURY

Volume 60, 2014

Research Question 2: Is there an improved quality of education at all levels?

Table 4 reveals lecturers' responses by gender to target items on improved quality of education at all levels. The significant values in Table 4 are all greater than 0.05 , which implies that the views of males and female lecturers on each target and the overall goal pertaining the achievement of the target of an improved quality of education at all levels do not vary significantly. The results reveal that the majority of the lecturers disagreed with the attainment of all the 9 parameters that would have implied an improved quality of education at all school levels.

Table 4. Chi-square analysis of the responses of male and female lecturers on contents pertaining to improved quality of education at all levels.

\begin{tabular}{|c|c|c|c|c|c|c|c|}
\hline \multirow{2}{*}{ Target Content } & \multirow{2}{*}{ Response } & \multicolumn{2}{|l|}{ Gender } & \multirow{2}{*}{ Total } & & \multirow{2}{*}{ df } & \multirow{2}{*}{$p$} \\
\hline & & Male & Female & & & & \\
\hline \multirow{2}{*}{$\begin{array}{l}\text { Eighty percent of primary school teach- } \\
\text { ers have acquired the minimum teaching } \\
\text { qualification (the National Certificate in } \\
\text { Education) }\end{array}$} & Agree & $162(158.1)$ & $54(57.9)$ & 216 & \multirow[b]{2}{*}{2.623} & \multirow[b]{2}{*}{1} & \multirow[b]{2}{*}{$0.105^{n s}$} \\
\hline & Disagree & $21(24.9)$ & $13(9.1)$ & 34 & & & \\
\hline \multirow{2}{*}{$\begin{array}{l}\text { Ninety percent of secondary school teach- } \\
\text { ers have obtained professional qualifica- } \\
\text { tions (B. Ed.; PGDE) }\end{array}$} & Agree & $162(164.0)$ & $62(60.0)$ & 224 & \multirow{2}{*}{0.847} & \multirow{2}{*}{1} & \multirow{2}{*}{$0.357^{n s}$} \\
\hline & Disagree & $21(19.0)$ & $5(7.0)$ & 26 & & & \\
\hline \multirow{2}{*}{$\begin{array}{l}\text { Eighty percent of teachers in tertiary institu- } \\
\text { tions have acquired pedagogical skills }\end{array}$} & Agree & $100(96.6)$ & $32(35.4)$ & 132 & \multirow{2}{*}{0.932} & \multirow{2}{*}{1} & \multirow{2}{*}{$0.334^{n s}$} \\
\hline & Disagree & $83(86.4)$ & $35(31.6)$ & 118 & & & \\
\hline \multirow{2}{*}{$\begin{array}{l}\text { Eighty percent of teachers at all levels are } \\
\text { professionals }\end{array}$} & Agree & $141(138.3)$ & $48(50.7)$ & 189 & \multirow{2}{*}{0.777} & \multirow{2}{*}{1} & \multirow{2}{*}{$0.378^{\text {ns }}$} \\
\hline & Disagree & $42(44.7)$ & $19(16.3)$ & 61 & & & \\
\hline \multirow{2}{*}{$\begin{array}{l}\text { Fifty percent of primary schools have con- } \\
\text { ducive teaching and learning environments }\end{array}$} & Agree & $21(22.0)$ & $9(8.0)$ & 30 & \multirow{2}{*}{0.178} & \multirow{2}{*}{1} & \multirow{2}{*}{$0.673^{n s}$} \\
\hline & Disagree & $162(161.0)$ & $58(59.0)$ & 220 & & & \\
\hline \multirow{2}{*}{$\begin{array}{l}\text { Sixty percent of secondary schools have } \\
\text { conducive teaching and learning environ- } \\
\text { ments }\end{array}$} & Agree & $20(19.0)$ & $6(7.0)$ & 26 & \multirow[b]{2}{*}{0.205} & \multirow[b]{2}{*}{1} & \multirow{2}{*}{$0.651^{\text {ns }}$} \\
\hline & Disagree & $163(164.0)$ & $61(60.0)$ & 224 & & & \\
\hline \multirow{2}{*}{$\begin{array}{l}\text { Sixty percent of tertiary schools have con- } \\
\text { ducive teaching and learning environments }\end{array}$} & Agree & $30(27.8)$ & $8(10.2)$ & 38 & \multirow{2}{*}{0.755} & \multirow{2}{*}{1} & \multirow{2}{*}{$0.385^{n s}$} \\
\hline & Disagree & $153(155.2)$ & $59(56.8)$ & 212 & & & \\
\hline Sixty percent of Head teachers and As- & Agree & $43(38.8)$ & $10(14.2)$ & 53 & & & \\
\hline $\begin{array}{l}\text { sistants undergo training in school level } \\
\text { management }\end{array}$ & Disagree & $140(144.2)$ & $57(52.8)$ & 197 & 2.157 & 1 & $0.142^{n s}$ \\
\hline There is an established, efficient institu- & Agree & $34(31.5)$ & $9(11.5)$ & 43 & & & \\
\hline $\begin{array}{l}\text { tional framework for monitoring learning } \\
\text { and teaching process at all levels }\end{array}$ & Disagree & $149(151.5)$ & $58(55.5)$ & 207 & 0.912 & 1 & $0.340^{n s}$ \\
\hline Overall responses to contents pertaining to & Agree & $79(77.6)$ & $27(28.4)$ & 106 & & 1 & 0 couns \\
\hline improved quality of education at all levels & Disagree & $104(105.4)$ & $40(38.6)$ & 144 & 160 & 1 & $0.084^{\circ 0}$ \\
\hline TOTAL (N) & & 183 & 67 & 250 & & & \\
\hline
\end{tabular}

Table 5 contains the responses of lecturers to items for improved quality of education at all levels, based on their ages. The significant values in Table 5 are all greater than 0.05 , which implies that the views of lecturers in the age-groups on each target and the overall goal pertain- 
Isaac Olakanmi ABIMBOLA, Esther Ore OMOSEWO, Johnson Enero UPAHI. Assessment of Education Policy Thrust of the National Economic Empowerment and Development Strategy (Needs) in Nigeria

ing the achievement of the target of an improved quality of education at all levels do not vary

significantly.

Table 5. Chi-square analysis of the responses of lecturers' age-groups on contents pertaining to improved quality of education at all levels.

\begin{tabular}{|c|c|c|c|c|c|c|c|c|}
\hline \multirow{2}{*}{ Target Content } & \multirow{2}{*}{$\begin{array}{l}\text { Re- } \\
\text { sponse }\end{array}$} & \multicolumn{3}{|c|}{ Age-group } & \multirow{2}{*}{ Total } & & \multirow{2}{*}{ df } & \multirow{2}{*}{$p$} \\
\hline & & $26-34$ & $35-44$ & $45+$ & & & & \\
\hline \multirow{2}{*}{$\begin{array}{l}\text { Eighty percent of primary } \\
\text { school teachers have acquired } \\
\text { the minimum teaching qualifi- } \\
\text { cation (the National Certificate } \\
\text { in Education) }\end{array}$} & Agree & $31(32.0)$ & $97(97.6)$ & 88 (86.4) & 216 & \multirow[b]{2}{*}{0.463} & \multirow[b]{2}{*}{2} & \multirow[b]{2}{*}{$0.793^{n s}$} \\
\hline & Disagree & $6(5.0)$ & $16(15.4)$ & $12(13.6)$ & 34 & & & \\
\hline \multirow{2}{*}{$\begin{array}{l}\text { Ninety percent of secondary } \\
\text { school teachers have obtained } \\
\text { professional qualifications (B. } \\
\text { Ed.; PGDE) }\end{array}$} & Agree & 34 (33.2) & $102(101.2)$ & $88(89.6)$ & 224 & \multirow[b]{2}{*}{0.537} & \multirow[b]{2}{*}{2} & \multirow[b]{2}{*}{$0.765^{n s}$} \\
\hline & Disagree & $3(3.8)$ & $11(11.8)$ & $12(10.4)$ & 26 & & & \\
\hline \multirow{2}{*}{$\begin{array}{l}\text { Eighty percent of teachers } \\
\text { in tertiary institutions have } \\
\text { acquired pedagogical skills }\end{array}$} & Agree & $21(19.5)$ & $60(59.7)$ & $51(52.8)$ & 132 & \multirow{2}{*}{0.366} & \multirow{2}{*}{2} & \multirow{2}{*}{$0.833^{\text {ns }}$} \\
\hline & Disagree & $16(17.5)$ & $53(53.3)$ & $49(47.2)$ & 118 & & & \\
\hline \multirow{2}{*}{$\begin{array}{l}\text { Eighty percent of teachers at } \\
\text { all levels are professionals }\end{array}$} & Agree & $30(28.0)$ & $89(85.4)$ & $70(75.6)$ & 189 & \multirow{2}{*}{2.915} & \multirow{2}{*}{2} & \multirow{2}{*}{$0.233^{\text {ns }}$} \\
\hline & Disagree & $7(9.0)$ & $24(27.6)$ & $30(24.4)$ & 61 & & & \\
\hline \multirow{2}{*}{$\begin{array}{l}\text { Fifty percent of primary } \\
\text { schools have conducive } \\
\text { teaching and learning environ- } \\
\text { ments }\end{array}$} & Agree & $3(4.4)$ & $17(13.6)$ & $10(12.0)$ & 30 & \multirow[b]{2}{*}{1.901} & \multirow[b]{2}{*}{2} & \multirow[b]{2}{*}{$0.387^{n s}$} \\
\hline & Disagree & 34 (32.6) & $96(99.4)$ & $90(88.0)$ & 220 & & & \\
\hline \multirow{2}{*}{$\begin{array}{l}\text { Sixty percent of secondary } \\
\text { schools have conducive } \\
\text { teaching and learning environ- } \\
\text { ments }\end{array}$} & Agree & $2(3.8)$ & $14(11.8)$ & $10(10.4)$ & 26 & \multirow[b]{2}{*}{1.488} & \multirow[b]{2}{*}{2} & \multirow[b]{2}{*}{$0.475^{n s}$} \\
\hline & Disagree & 35 (33.2) & $99(101.2)$ & $90(89.6)$ & 224 & & & \\
\hline \multirow{2}{*}{$\begin{array}{l}\text { Sixty percent of tertiary } \\
\text { schools have conducive } \\
\text { teaching and learning environ- } \\
\text { ments }\end{array}$} & Agree & $4(5.6)$ & $15(17.2)$ & $19(15.2)$ & 38 & \multirow[b]{2}{*}{1.998} & \multirow[b]{2}{*}{2} & \\
\hline & Disagree & $33(31.4)$ & $98(95.8)$ & $81(84.8)$ & 212 & & & $0.368^{n s}$ \\
\hline Sixty percent of Head teach- & Agree & $9(7.8)$ & $21(24.0)$ & $23(21.2)$ & 53 & & & \\
\hline $\begin{array}{l}\text { ers and Assistants undergo } \\
\text { training in school level man- } \\
\text { agement }\end{array}$ & Disagree & $28(29.2)$ & $92(89.0)$ & $77(78.8)$ & 197 & 0.873 & 2 & $0.646^{n s}$ \\
\hline There is an established, ef- & Agree & $5(6.4)$ & $25(19.4)$ & $13(17.2)$ & 43 & & & \\
\hline $\begin{array}{l}\text { ficient institutional framework } \\
\text { for monitoring learning and } \\
\text { teaching process at all levels }\end{array}$ & Disagree & $32(30.6)$ & $88(93.6)$ & $87(82.8)$ & 207 & 3.515 & 2 & $0.172^{\text {ns }}$ \\
\hline Overall responses to contents & Agree & $15(15.7)$ & $49(47.9)$ & $42(42.4)$ & 106 & & & \\
\hline $\begin{array}{l}\text { pertaining to improved quality } \\
\text { of education at all levels }\end{array}$ & Disagree & $22(21.3)$ & $64(65.1)$ & $58(57.6)$ & 144 & 157 & 2 & $0.561^{n s}$ \\
\hline TOTAL (N) & & 37 & 113 & 100 & 250 & & & \\
\hline
\end{tabular}

Note. $p \geq 0.05$ (ns, not significant). The expected frequencies appear in parentheses beside agree and disagree responses. 
Isaac Olakanmi ABIMBOLA, Esther Ore OMOSEWO, Johnson Enero UPAHI. Assessment of Education Policy Thrust of the National Economic Empowerment and Development Strategy (Needs) in Nigeria

EMS

OF EDUCATION

IN THE $21^{\text {st }}$ CENTURY

Volume 60, 2014

34

preneurial skills to live meaningfully?

Table 6 presents the responses of male and female lecturers to items on students acquiring basic life, technical and entrepreneurial skills. The majority of male and female lecturers disagreed with the achievement of the first parameter that aimed at equipping Nigerians to able to live meaningfully and to contribute to national development with just the acquisition of literacy and numeracy skills at the completion of basic education. The results further revealed that both male and female lecturers disagreed with the achievement of the quoted percentages of secondary school and tertiary institution graduates who have acquired adequate technical and entrepreneurial skills to be self-employed and wealth creators. It is, therefore, the views of the majority of male and female lecturers that, the goal of using education as a tool for improving the quality of life through skill acquisition and job creation for poverty reduction is still at its lowest ebb.

The significant values in Table 6 are all greater than 0.05 which implies that the views of male and female lecturers on each target and the overall goal pertaining to students of all levels having acquired basic life, technical and entrepreneurial skills to live meaningfully do not vary significantly.

Table 6. Chi-square analysis of the responses of male and female lecturers on contents pertaining to students of all levels having acquired basic life, technical and entrepreneurial skills to live meaningfully.

\begin{tabular}{|c|c|c|c|c|c|c|c|}
\hline \multirow{2}{*}{ Target Content } & \multirow{2}{*}{$\begin{array}{l}\text { Re- } \\
\text { sponse }\end{array}$} & \multicolumn{2}{|l|}{ Gender } & \multirow{2}{*}{ Total } & & \multirow{2}{*}{ df } & \multirow{2}{*}{$p$} \\
\hline & & Male & Female & & & & \\
\hline \multirow{2}{*}{$\begin{array}{l}\text { Nigerians who have completed basic educa- } \\
\text { tion have acquired the literacy, numeracy } \\
\text { and basic life skills need to live meaningful } \\
\text { lives and to contribute to national develop- } \\
\text { ment }\end{array}$} & Agree & $34(32.9)$ & $11(12.1)$ & 45 & \multirow[b]{2}{*}{0.155} & \multirow[b]{2}{*}{1} & \multirow[b]{2}{*}{$0.694^{\text {ns }}$} \\
\hline & Disagree & 149 (150.1) & $56(54.9)$ & 205 & & & \\
\hline \multirow{2}{*}{$\begin{array}{l}\text { Fifty percent of secondary school students } \\
\text { have access to good-quality vocational and } \\
\text { entrepreneurial education }\end{array}$} & Agree & $47(49.8)$ & $21(18.2)$ & 68 & \multirow{2}{*}{0.794} & \multirow{2}{*}{1} & \multirow{2}{*}{$0.373^{n s}$} \\
\hline & Disagree & $136(133.2)$ & $46(48.8)$ & 182 & & & \\
\hline \multirow{2}{*}{$\begin{array}{l}\text { Fifty percent of tertiary education graduates } \\
\text { have acquired sufficient technical skills, } \\
\text { entrepreneurial skills and the knowledge to } \\
\text { be self-employed and wealth creators }\end{array}$} & Agree & 77 (78.2) & $30(28.7)$ & 107 & \multirow[b]{2}{*}{0.146} & \multirow[b]{2}{*}{1} & \multirow[b]{2}{*}{$0.702^{\text {ns }}$} \\
\hline & Disagree & $106(104.7)$ & $37(38.3)$ & 143 & & & \\
\hline \multirow{2}{*}{$\begin{array}{l}\text { Overall responses to contents pertaining to } \\
\text { students of all levels have acquired basic } \\
\text { life, technical and entrepreneurial skills to } \\
\text { live meaningfully }\end{array}$} & Agree & $53(53.4)$ & $20(19.6)$ & 73 & \multirow[b]{2}{*}{1.164} & \multirow[b]{2}{*}{1} & \multirow[b]{2}{*}{$0.281^{\text {ns }}$} \\
\hline & Disagree & $130(129.6)$ & $47(47.4)$ & 177 & & & \\
\hline TOTAL (N) & & 183 & 67 & 250 & & & \\
\hline
\end{tabular}

Note. $p \geq 0.05$ (ns, not significant). The expected frequencies appear in parentheses beside agree and disagree responses.

Table 7 presents lecturers' responses to the items on the targeted percentages of senior school and university graduates who have acquired basic life, vocational, technical and entrepreneurial skills to live meaningfully. The significant values in Table 7 are all greater than 0.05 , which implies that the views of lecturers in the age-groups on each target and the overall goal pertaining to students of all levels having acquired basic life, technical and entrepreneurial skills to live meaningfully do not vary significantly. 
Table 7. Chi-square analysis of the responses of lecturers' age-groups on contents pertaining to students of all levels having acquired basic life, technical and entrepreneurial skills to live meaningfully.

\begin{tabular}{|c|c|c|c|c|c|c|c|c|}
\hline \multirow{2}{*}{ Target Content } & \multirow{2}{*}{ Response } & \multicolumn{3}{|c|}{ Age-group } & \multirow{2}{*}{ - Total } & & \multirow{2}{*}{ Df } & \multirow{2}{*}{ Sig. } \\
\hline & & $26-34$ & $35-44$ & $45+$ & & & & \\
\hline \multirow{2}{*}{$\begin{array}{l}\text { Nigerians who have completed } \\
\text { basic education have acquired } \\
\text { the literacy, numeracy and basic } \\
\text { life skills need to live meaningful } \\
\text { lives and to contribute to national } \\
\text { development }\end{array}$} & Agree & $4(6.7)$ & $19(20.3)$ & $22(18.0)$ & 45 & \multirow[b]{2}{*}{2.487} & \multirow[b]{2}{*}{2} & \multirow[b]{2}{*}{$0.288^{\text {ns }}$} \\
\hline & Disagree & $33(30.3)$ & $94(92.7)$ & $78(82.0)$ & 205 & & & \\
\hline \multirow{2}{*}{$\begin{array}{l}\text { Fifty percent of secondary school } \\
\text { students have access to good- } \\
\text { quality vocational and entrepre- } \\
\text { neurial education }\end{array}$} & Agree & $10(10.1)$ & $35(30.7)$ & $23(27.2)$ & 68 & \multirow[b]{2}{*}{1.704} & \multirow[b]{2}{*}{2} & \multirow[b]{2}{*}{$0.427^{n s}$} \\
\hline & Disagree & $27(26.9)$ & $78(82.3)$ & 77 (72.8) & 182 & & & \\
\hline \multirow{2}{*}{$\begin{array}{l}\text { Fifty percent of tertiary education } \\
\text { graduates have acquired suf- } \\
\text { ficient technical skills, entrepre- } \\
\text { neurial skills and the knowledge } \\
\text { to be self-employed and wealth } \\
\text { creators }\end{array}$} & Agree & $15(15.8)$ & $44(48.4)$ & $48(42.8)$ & 107 & \multirow[b]{2}{*}{1.870} & \multirow[b]{2}{*}{2} & \multirow[b]{2}{*}{$0.393^{\text {ns }}$} \\
\hline & Disagree & $22(21.2)$ & $69(64.6)$ & $52(57.2)$ & 143 & & & \\
\hline \multirow{2}{*}{$\begin{array}{l}\text { Overall responses to contents } \\
\text { pertaining to students of all levels } \\
\text { have acquired basic life, techni- } \\
\text { cal and entrepreneurial skills to } \\
\text { live meaningfully }\end{array}$} & Agree & $10(10.8)$ & $32(33.0)$ & $31(29.2)$ & 73 & \multirow[b]{2}{*}{1.883} & \multirow[b]{2}{*}{2} & \multirow[b]{2}{*}{$0.390^{\text {ns }}$} \\
\hline & Disagree & $27(26.2)$ & $81(80.0)$ & $69(70.8)$ & 177 & & & \\
\hline TOTAL (N) & & 37 & 113 & 100 & 250 & & & \\
\hline
\end{tabular}

Research Question 4: Do the periodic review and implementation of the secondary school curriculum meet the requirements of higher education and the world of work?

Table 8 presents age-group responses of lecturers to items on periodic review and implementation of the secondary school curriculum to meet the requirement of higher education and the world of work. The significant values in Table 8 are all greater than 0.05 , which implies that the views of male and female lecturers on each target and the overall goal pertaining to the periodic review and implementation of the secondary school curriculum meeting the requirement of higher education and the world of work do not vary significantly. From the table, it can be deduced that, while there has been a considerable periodic review of the secondary school curricula, the majority of the male and female lecturers disagreed with the assertion that such revised curricula reflect the dynamism of the society and the emerging global issues, and the involvement of local craftspersons for effective delivery of vocational education in schools. 
Isaac Olakanmi ABIMBOLA, Esther Ore OMOSEWO, Johnson Enero UPAHI. Assessment of Education Policy Thrust of the National Economic Empowerment and Development Strategy (Needs) in Nigeria

PROBLEMS

OF EDUCATION

IN THE $21^{\text {st }}$ CENTURY

Volume 60,2014

Table 8. Chi-square analysis of the responses of male and female lecturers on contents pertaining to the periodic review and implementation of the secondary school curriculum meeting the requirement of higher education and the world of work.

\begin{tabular}{|c|c|c|c|c|c|c|c|}
\hline \multirow{2}{*}{ Target Content } & \multirow{2}{*}{ Response } & \multicolumn{2}{|l|}{ Gender } & \multirow{2}{*}{ Total } & & \multirow{2}{*}{ df } & \multirow{2}{*}{$p$} \\
\hline & & Male & Female & & & & \\
\hline \multirow{2}{*}{$\begin{array}{l}\text { There is completed curricular revision exer- } \\
\text { cise that reflects the dynamism of society and } \\
\text { emerging global issues }\end{array}$} & Agree & $49(49.8)$ & $19(18.2)$ & 68 & \multirow{2}{*}{0.062} & \multirow{2}{*}{1} & \multirow{2}{*}{$0.803^{\text {ns }}$} \\
\hline & Disagree & $134(133.2)$ & $48(48.8)$ & 182 & & & \\
\hline \multirow{2}{*}{$\begin{array}{l}\text { There are rehabilitated vocational basic tech- } \\
\text { nology and resource centers nationwide }\end{array}$} & Agree & $90(90.0)$ & $33(33.0)$ & 123 & \multirow{2}{*}{0.000} & \multirow{2}{*}{1} & \multirow{2}{*}{$0.992^{n_{5}}$} \\
\hline & Disagree & $93(93.0)$ & $34(34.0)$ & 127 & & & \\
\hline \multirow{2}{*}{$\begin{array}{l}\text { There established new basic technology and } \\
\text { resource centers nationwide }\end{array}$} & Agree & $81(82.0)$ & $31(30.0)$ & 112 & \multirow{2}{*}{0.080} & \multirow{2}{*}{1} & \multirow{2}{*}{$0.778^{n}$} \\
\hline & Disagree & $102(101.0)$ & $36(37.0)$ & 138 & & & \\
\hline \multirow{2}{*}{$\begin{array}{l}\text { There are productions of educational materi- } \\
\text { als that reflect the revised curricula }\end{array}$} & Agree & $93(92.2)$ & $33(33.8)$ & 126 & \multirow{2}{*}{0.048} & \multirow{2}{*}{1} & \multirow{2}{*}{$0.826^{n s}$} \\
\hline & Disagree & $90(90.8)$ & $34(33.2)$ & 124 & & & \\
\hline \multirow{2}{*}{$\begin{array}{l}\text { There are well-established libraries and } \\
\text { information resource centers for teachers and } \\
\text { students to complement formal and life-long } \\
\text { education and created awareness of the } \\
\text { importance }\end{array}$} & Agree & 82 (81.3) & $29(29.7)$ & 111 & \multirow[b]{2}{*}{0.046} & \multirow[b]{2}{*}{1} & \multirow[b]{2}{*}{$0.830^{\text {ns }}$} \\
\hline & Disagree & $101(101.7)$ & $38(37.3)$ & 139 & & & \\
\hline \multirow{2}{*}{$\begin{array}{l}\text { There are involvements of local craftspeople } \\
\text { in the delivery of vocational education in } \\
\text { schools }\end{array}$} & Agree & $55(58.6)$ & $25(21.4)$ & 80 & \multirow{2}{*}{1.188} & \multirow{2}{*}{1} & \multirow{2}{*}{$0.276^{n s}$} \\
\hline & Disagree & $128(124.4)$ & $42(45.6)$ & 170 & & & \\
\hline \multirow{2}{*}{$\begin{array}{l}\text { Overall responses to contents pertaining to } \\
\text { the periodic review and implementation of } \\
\text { the secondary school curriculum meeting } \\
\text { the requirement of higher education and the } \\
\text { world of work }\end{array}$} & Agree & $75(75.4)$ & $28(27.6)$ & 103 & \multirow[b]{2}{*}{0.164} & \multirow[b]{2}{*}{1} & \multirow[b]{2}{*}{$0.685^{n s}$} \\
\hline & Disagree & $108(107.6)$ & $39(39.4)$ & 147 & & & \\
\hline TOTAL (N) & & 183 & 67 & 250 & & & \\
\hline
\end{tabular}

Note. $p \geq 0.05$ (ns, not significant). The expected frequencies appear in parentheses beside agree and disagree responses

Table 9 shows lecturers' responses to items on periodic review and implementation of the secondary school curriculum meeting the requirement of higher education and the world of work, based on their age groups. The significant values in Table 9 are all greater than 0.05 , which implies that the views of lecturers in the age-groups on each target and the overall goal pertaining to the periodic review and implementation of the secondary school curriculum meeting the requirement of higher education and the world of work do not vary significantly. 
Table 9. Chi-square analysis of the responses of lecturers' age-groups on contents pertaining to the periodic review and implementation of the secondary school curriculum meeting the requirement of higher education and the world of work.

\begin{tabular}{|c|c|c|c|c|c|c|c|c|}
\hline \multirow{2}{*}{ Target Content } & \multirow{2}{*}{$\begin{array}{l}\mathrm{Re}- \\
\text { sponse }\end{array}$} & \multicolumn{3}{|c|}{ Age-group } & \multirow{2}{*}{ Total } & \multirow{2}{*}{\multicolumn{2}{|c|}{0}} & \multirow{2}{*}{$p$} \\
\hline & & $26-34$ & $35-44$ & $45+$ & & & & \\
\hline \multirow{3}{*}{$\begin{array}{l}\text { There is completed curricular revision } \\
\text { exercise that reflects the dynamism of } \\
\text { society and emerging global } \\
\text { issues }\end{array}$} & Agree & $8(10.1)$ & $30(30.7)$ & $30(27.2)$ & 68 & \multirow{3}{*}{1.002} & \multirow{3}{*}{2} & \multirow{3}{*}{$0.606^{n s}$} \\
\hline & & & & & & & & \\
\hline & Disagree & $29(26.9)$ & $83(82.3)$ & $70(72.8)$ & 182 & & & \\
\hline \multirow{2}{*}{$\begin{array}{l}\text { There are rehabilitated vocational } \\
\text { basic technology and resource centers } \\
\text { nationwide }\end{array}$} & Agree & $18(18.2)$ & $54(55.6)$ & $51(49.2)$ & 123 & \multirow{2}{*}{0.224} & \multirow{2}{*}{2} & \multirow{2}{*}{$0.894^{\text {ns }}$} \\
\hline & Disagree & $19(18.8)$ & $59(57.4)$ & $49(50.8)$ & 127 & & & \\
\hline \multirow{2}{*}{$\begin{array}{l}\text { There established new basic technol- } \\
\text { ogy and resource centers nationwide }\end{array}$} & Agree & $17(16.6)$ & $49(50.6)$ & $46(44.8)$ & 112 & \multirow{2}{*}{0.172} & \multirow{2}{*}{2} & \multirow{2}{*}{$0.917^{\text {ns }}$} \\
\hline & Disagree & $20(20.4)$ & $64(62.4)$ & $54(55.2)$ & 138 & & & \\
\hline \multirow{2}{*}{$\begin{array}{l}\text { There are productions of educational } \\
\text { materials that reflect the revised cur- } \\
\text { ricula }\end{array}$} & Agree & $17(18.6)$ & $58(57.0)$ & $51(50.4)$ & 126 & \multirow[b]{2}{*}{0.347} & \multirow[b]{2}{*}{2} & \multirow[b]{2}{*}{$0.841^{n s}$} \\
\hline & Disagree & $20(18.4)$ & $55(56.0)$ & $49(49.6)$ & 124 & & & \\
\hline \multirow{2}{*}{$\begin{array}{l}\text { There are well-established libraries } \\
\text { and information resource centers for } \\
\text { teachers and students to complement } \\
\text { formal and life-long education and cre- } \\
\text { ated awareness of the importance }\end{array}$} & Agree & $16(16.4)$ & $52(50.2)$ & $43(44.4)$ & 111 & \multirow[b]{2}{*}{0.219} & \multirow[b]{2}{*}{2} & \multirow[b]{2}{*}{$0.896^{n s}$} \\
\hline & Disagree & $21(20.6)$ & $61(62.8)$ & $57(55.6)$ & 139 & & & \\
\hline \multirow{2}{*}{$\begin{array}{l}\text { There are involvements of local craft- } \\
\text { speople in the delivery of vocational } \\
\text { education in schools }\end{array}$} & Agree & $11(11.8)$ & $36(36.2)$ & $33(32.0)$ & 80 & \multirow[b]{2}{*}{0.135} & \multirow[b]{2}{*}{2} & \multirow[b]{2}{*}{$0.935^{n s}$} \\
\hline & Disagree & $26(25.2)$ & $77(76.8)$ & $67(68.0)$ & 170 & & & \\
\hline \multirow{2}{*}{$\begin{array}{l}\text { Overall responses to contents pertain- } \\
\text { ing to the periodic review and imple- } \\
\text { mentation of the secondary school } \\
\text { curriculum meeting the requirement of } \\
\text { higher education and the world of work }\end{array}$} & Agree & $15(15.2)$ & $46(46.6)$ & $42(41.2)$ & 103 & \multirow[b]{2}{*}{1.055} & \multirow[b]{2}{*}{2} & \multirow[b]{2}{*}{$0.590^{n s}$} \\
\hline & Disagree & $22(21.8)$ & $67(66.4)$ & $58(58.8)$ & 147 & & & \\
\hline TOTAL $(\mathrm{N})$ & & 37 & 113 & 100 & 250 & & & \\
\hline
\end{tabular}

Note. $p \geq 0.05$ (ns, not significant). The expected frequencies appear in parentheses beside agree and disagree responses.

Research Question 5: Is there an improved partnership among private sectors and local communities with respect to support and fund?

Table 10 reveals lecturers' gender responses to target items on improved partnership among private sectors and local communities with respect to support and fund for education. The results in table 10 for each of the items are all greater than 0.05 , which implies that the views of male and female lecturers on each target and the overall goal pertaining to an improved partnership among private sectors and local communities with respect to support and fund do not vary significantly. It is, therefore, the view of the majority of the male and female lecturers that the target goal of improving the partnership of private sectors and the local communities with respect to support and funding is yet to be fully realized. 
Isaac Olakanmi ABIMBOLA, Esther Ore OMOSEWO, Johnson Enero UPAHI. Assessment of Education Policy Thrust of the National Economic Empowerment and Development Strategy (Needs) in Nigeria

PROBLEMS

OF EDUCATION

IN THE $21^{\text {st }}$ CENTURY

Volume 60, 2014

38

Table 10. Chi-square analysis of the responses of male and female lecturers on contents pertaining to an improved partnership among private sectors and local communities with respect to support and fund for education.

\begin{tabular}{|c|c|c|c|c|c|c|c|}
\hline \multirow{2}{*}{ Target Content } & \multirow{2}{*}{$\begin{array}{l}\text { Re- } \\
\text { sponse }\end{array}$} & \multicolumn{2}{|l|}{ Gender } & \multirow{2}{*}{ Total } & & \multirow{2}{*}{$p$} \\
\hline & & Male & Female & & & df & \\
\hline \multirow{2}{*}{$\begin{array}{l}\text { There is an improved collaboration among } \\
\text { major stakeholders }\end{array}$} & Agree & $2529.3)$ & $15(10.7)$ & 40 & \multirow{2}{*}{2.779} & \multirow{2}{*}{1} & \multirow{2}{*}{$0.096^{n s}$} \\
\hline & Disagree & $158(153.7)$ & $52(56.3)$ & 210 & & & \\
\hline \multirow{2}{*}{$\begin{array}{l}\text { Eighty percent community involvement in the } \\
\text { management of schools have been achieved }\end{array}$} & Agree & $52(54.9)$ & $23(20.1)$ & 75 & \multirow{2}{*}{.817} & \multirow{2}{*}{1} & \multirow{2}{*}{$0.366^{n s}$} \\
\hline & Disagree & $131(128.1)$ & $44(46.9)$ & 175 & & & \\
\hline \multirow{2}{*}{$\begin{array}{l}\text { Sixty percent private sector involvement in } \\
\text { managing and funding education has been } \\
\text { achieved }\end{array}$} & Agree & $57(56.4)$ & $20(20.6)$ & 77 & \multirow{2}{*}{.039} & \multirow{2}{*}{1} & \multirow{2}{*}{$0.844^{\text {ns }}$} \\
\hline & Disagree & $126(126.6)$ & $47(46.4)$ & 173 & & & \\
\hline \multirow{2}{*}{$\begin{array}{l}\text { Two percent education tax and enforced } 100 \\
\text { percent compliance has been retained and } \\
\text { sustained }\end{array}$} & Agree & $35(37.3)$ & $16(13.7)$ & 51 & \multirow[b]{2}{*}{.683} & \multirow[b]{2}{*}{1} & \multirow[b]{2}{*}{$0.409^{n s}$} \\
\hline & Disagree & $148(145.7)$ & $51(53.3)$ & 199 & & & \\
\hline \multirow{2}{*}{$\begin{array}{l}\text { Overall responses to contents pertaining to an } \\
\text { improved partnership among private sectors } \\
\text { and local communities with respect to support } \\
\text { and fund }\end{array}$} & Agree & $42(44.7)$ & $19(16.3)$ & 61 & \multirow[b]{2}{*}{.777} & \multirow[b]{2}{*}{1} & \multirow[b]{2}{*}{$0.378^{n s}$} \\
\hline & Disagree & 141 (138.3) & $48(50.7)$ & 189 & & & \\
\hline TOTAL (N) & & 183 & 67 & 250 & & & \\
\hline
\end{tabular}

Table 11 presents lecturers' age-group responses to items on improved partnership among private sectors and local communities with respect to support and fund for education. The significant values in Table 11 are all greater than 0.05 , which implies that the views of lecturers in the age-groups on each target and the overall goal pertaining to an improved partnership among private sectors and local communities with respect to support and fund do not vary significantly. 
Table 11. Chi-square analysis of the responses of lecturers' age-groups on contents pertaining to an improved partnership among private sectors and local communities with respect to support and fund.

\begin{tabular}{|c|c|c|c|c|c|c|c|c|}
\hline \multirow{2}{*}{ Target Content } & \multirow{2}{*}{$\begin{array}{l}\text { Re- } \\
\text { sponse }\end{array}$} & \multicolumn{3}{|c|}{ Age-group } & \multirow{2}{*}{$\begin{array}{l}\text { To- } \\
\text { tal }\end{array}$} & & \multirow{2}{*}{ df } & \multirow{2}{*}{$p$} \\
\hline & & $26-34$ & $35-44$ & $45+$ & & & & \\
\hline \multirow{2}{*}{$\begin{array}{l}\text { There is an improved collaboration } \\
\text { among major stakeholders }\end{array}$} & Agree & $4(5.9)$ & $22(18.1)$ & $14(16.0)$ & 40 & \multirow{2}{*}{2.051} & \multirow[t]{2}{*}{$\Rightarrow$} & \multirow{2}{*}{$0.359^{\text {ns }}$} \\
\hline & Disagree & 33 (31.1) & $91(94.9)$ & $86(84.0)$ & 210 & & & \\
\hline \multirow{2}{*}{$\begin{array}{l}\text { Eighty percent community involve- } \\
\text { ment in the management of schools } \\
\text { have been achieved }\end{array}$} & Agree & 14 (11.1) & $31(33.9)$ & $30(30.0)$ & 75 & \multirow{2}{*}{1.437} & \multirow{2}{*}{2} & \multirow{2}{*}{$0.488^{\text {ns }}$} \\
\hline & Disagree & $23(25.9)$ & $82(79.1)$ & $70(70.0)$ & 175 & & & \\
\hline \multirow{2}{*}{$\begin{array}{l}\text { Sixty percent private sector involve- } \\
\text { ment in managing and funding } \\
\text { education has been achieved }\end{array}$} & Agree & $12(11.4)$ & $36(34.8)$ & $29(30.8)$ & 77 & \multirow[b]{2}{*}{.258} & \multirow[b]{2}{*}{2} & \multirow{2}{*}{$0.879^{\text {ns }}$} \\
\hline & Disagree & $25(25.6)$ & $77(78.2)$ & 71 (69.2) & 173 & & & \\
\hline \multirow{2}{*}{$\begin{array}{l}\text { Two percent education tax and en- } \\
\text { forced } 100 \text { percent compliance has } \\
\text { been retained and sustained }\end{array}$} & Agree & $10(7.5)$ & $24(23.1)$ & $17(20.4)$ & 51 & \multirow{2}{*}{1.762} & \multirow{2}{*}{2} & \multirow{2}{*}{$0.414^{n s}$} \\
\hline & Disagree & $27(29.5)$ & $89(89.9)$ & $83(79.6)$ & 199 & & & \\
\hline \multirow{2}{*}{$\begin{array}{l}\text { Overall responses to contents } \\
\text { pertaining to an improved partner- } \\
\text { ship among private sectors and local } \\
\text { communities with respect to support } \\
\text { and fund }\end{array}$} & Agree & $10(9.0)$ & $28(27.6)$ & $23(24.4)$ & 61 & \multirow[b]{2}{*}{.750} & \multirow[b]{2}{*}{2} & \multirow[b]{2}{*}{$0.687^{\mathrm{ns}}$} \\
\hline & Disagree & $27(28.0)$ & $85(85.4)$ & $77(75.6)$ & 189 & & & \\
\hline TOTAL (N) & & 37 & 113 & 100 & 250 & & & \\
\hline
\end{tabular}

Note. $p \geq 0.05$ (ns, not significant). The expected frequencies appear in parentheses beside agree and disagree responses.

Research Question 6: Is there an improved level of ICT capabilities among students, their teachers and university lecturers?

Table 12 presents the responses of male and female lecturers to items on the improved level of ICT capabilities among students, teachers and university lecturers. The significant values in Table 12 are all greater than 0.05 , except for Item F6 and the overall responses to the contents $(F)$ which have their significant values less than 0.05 . This implies that the views of male and female lecturers on each of the 7 targets, except for target F6 and the average goal responses do not vary significantly. The views of male and female lecturers on the target that $80 \%$ of tertiary institutions have functional information and communication technology facilities and the overall responses pertaining to an improved level of ICT capabilities among students, their teachers and university lecturers vary significantly. It is, therefore, the views of the majority of the lecturers on item 6 , that $80 \%$ of tertiary institutions have functional information and communication technology facilities. However, this is not sufficient enough to conclude that there is an improved level of ICTs capabilities among students, their teachers and university lecturers. 
Isaac Olakanmi ABIMBOLA, Esther Ore OMOSEWO, Johnson Enero UPAHI. Assessment of Education Policy Thrust of the National Economic Empowerment and Development Strategy (Needs) in Nigeria

PROBLEMS

OF EDUCATION

IN THE $21^{\text {st }}$ CENTURY

Volume 60, 2014

40

Table 12. Chi-square analysis of the responses of male and female lecturers on contents pertaining to an improved level of ict capabilities among students, their teachers and university lecturers.

\begin{tabular}{|c|c|c|c|c|c|c|c|}
\hline \multirow{2}{*}{ Target Content } & \multirow{2}{*}{ Response } & \multicolumn{2}{|l|}{ Gender } & \multirow{2}{*}{ Total } & & \multirow{2}{*}{ df } & \multirow{2}{*}{$p$} \\
\hline & & Male & Female & & & & \\
\hline \multirow{2}{*}{$\begin{array}{l}\text { Ten percent of primary school graduates are } \\
\text { computer literate }\end{array}$} & Agree & $61(62.2)$ & $24(22.8)$ & 85 & \multirow{2}{*}{0.135} & \multirow{2}{*}{1} & \multirow{2}{*}{$0.713^{n s}$} \\
\hline & Disagree & $122(120.8)$ & $43(44.2)$ & 165 & & & \\
\hline \multirow{2}{*}{$\begin{array}{l}\text { Eighty percent of secondary school gradu- } \\
\text { ates are computer literate }\end{array}$} & Agree & $52(48.3)$ & $14(17.7)$ & 66 & \multirow{2}{*}{1.427} & \multirow{2}{*}{1} & \multirow{2}{*}{$0.232^{n s}$} \\
\hline & Disagree & $131(134.7)$ & $53(49.3)$ & 184 & & & \\
\hline \multirow{2}{*}{$\begin{array}{l}\text { Eighty percent of graduates of tertiary institu- } \\
\text { tions are computer literate }\end{array}$} & Agree & $60(59.3)$ & $21(21.7)$ & 81 & \multirow{2}{*}{0.047} & \multirow{2}{*}{1} & \multirow{2}{*}{$0.829^{n s}$} \\
\hline & Disagree & $123(123.7)$ & $46(45.3)$ & 169 & & & \\
\hline \multirow{2}{*}{$\begin{array}{l}\text { Fifty percent of school managers and propri- } \\
\text { etors are computer literate }\end{array}$} & Agree & $60(63.0)$ & $26(23.0)$ & 86 & \multirow{2}{*}{0.787} & \multirow{2}{*}{1} & \multirow{2}{*}{$0.375^{n s}$} \\
\hline & Disagree & $123(120.0)$ & $41(44.0)$ & 164 & & & \\
\hline \multirow{2}{*}{$\begin{array}{l}\text { Thirty percent of secondary schools have } \\
\text { functional information and communication } \\
\text { technology facilities }\end{array}$} & Agree & $68(71.0)$ & $29(26.0)$ & 97 & \multirow[b]{2}{*}{0.775} & \multirow[b]{2}{*}{1} & \multirow[b]{2}{*}{$0.397^{n s}$} \\
\hline & Disagree & $115(112.0)$ & $38(41.0)$ & 153 & & & \\
\hline \multirow{2}{*}{$\begin{array}{l}\text { Eighty percent of tertiary institutions have } \\
\text { functional information and communication } \\
\text { technology facilities }\end{array}$} & Agree & $73(82.0)$ & $39(30.0)$ & 112 & \multirow{2}{*}{6.655} & \multirow[b]{2}{*}{1} & \multirow{2}{*}{$0.010^{s}$} \\
\hline & Disagree & $110(101.0)$ & $28(37.0)$ & 138 & & & \\
\hline \multirow{2}{*}{$\begin{array}{l}\text { Fifty percent of teachers at all levels are } \\
\text { trained in computer skills }\end{array}$} & Agree & 79 (82.7) & $34(30.3)$ & 113 & \multirow{2}{*}{1.137} & \multirow{2}{*}{1} & \multirow{2}{*}{$0.286^{n s}$} \\
\hline & Disagree & $104(100.3)$ & $33(36.7)$ & 137 & & & \\
\hline \multirow{2}{*}{$\begin{array}{l}\text { Overall responses to contents pertaining to } \\
\text { an improved level of ICT capabilities among } \\
\text { students, their teachers and university } \\
\text { lecturers }\end{array}$} & Agree & $65(67.3)$ & $27(24.7)$ & 92 & & & \\
\hline & Disagree & $118(115.7)$ & $40(42.3)$ & 158 & 4.728 & 1 & $0.030^{\mathrm{s}}$ \\
\hline TOTAL (N) & & 183 & 67 & 250 & & & \\
\hline
\end{tabular}

Note. $p \geq .05$ (ns, not significant). $p \leq 0.05$ (s, significant). The expected frequencies appear in parentheses beside agree and disagree responses.

Table 13 shows lecturers' age-group responses to items on the improved level of ICT capabilities among students, teachers and university lecturers. The significant values in Table 13 are all greater than 0.05 which implies that the views of lecturers in the age-groups on each of the targets and the overall goal pertaining to an improved level of ICT capabilities among students, their teachers and university lecturers do not vary significantly. 
Table 13. Chi-square analysis of the responses of lecturers' age-groups on contents pertaining to an improved level of ict capabilities among students, their teachers and university lecturers.

\begin{tabular}{|c|c|c|c|c|c|c|c|c|}
\hline \multirow{2}{*}{ Target Content } & \multirow{2}{*}{ Response } & \multicolumn{3}{|l|}{ Age-group } & \multirow{2}{*}{ Total } & & \multirow{2}{*}{$d f$} & \multirow{2}{*}{$p$} \\
\hline & & $26-34$ & $35-44$ & $45+$ & & & & \\
\hline \multirow{2}{*}{$\begin{array}{l}\text { Ten percent of primary school } \\
\text { graduates are computer literate }\end{array}$} & Agree & $14(12.6)$ & $38(38.4)$ & $33(34.0)$ & 85 & \multirow{2}{*}{0.294} & \multirow{2}{*}{2} & \multirow{2}{*}{$0.863^{n s}$} \\
\hline & Disagree & $23(24.4)$ & $75(74.6)$ & $67(66.0)$ & 165 & & & \\
\hline \multirow{2}{*}{$\begin{array}{l}\text { Eighty percent of secondary } \\
\text { school graduates are computer } \\
\text { literate }\end{array}$} & Agree & $11(9.8)$ & $33(29.8)$ & $22(26.4)$ & 66 & \multirow[b]{2}{*}{1.665} & \multirow[b]{2}{*}{2} & \multirow[b]{2}{*}{$0.435^{n s}$} \\
\hline & Disagree & $26(27.2)$ & $80(83.2)$ & $78(73.6)$ & 184 & & & \\
\hline \multirow{2}{*}{$\begin{array}{l}\text { Eighty percent of graduates of } \\
\text { tertiary institutions are compu- } \\
\text { ter literate }\end{array}$} & Agree & $12(12.0)$ & $37(36.6)$ & $32(32.4)$ & 81 & \multirow{2}{*}{0.013} & \multirow{2}{*}{2} & \multirow{2}{*}{$0.993^{n s}$} \\
\hline & Disagree & $25(25.0)$ & $76(76.4)$ & $68(67.6)$ & 169 & & & \\
\hline \multirow{2}{*}{$\begin{array}{l}\text { Fifty percent of school } \\
\text { managers and proprietors are } \\
\text { computer literate }\end{array}$} & Agree & $14(12.7)$ & $39(38.9)$ & $33(34.4)$ & 86 & \multirow{2}{*}{0.281} & \multirow{2}{*}{2} & \multirow{2}{*}{$0.869^{\text {ns }}$} \\
\hline & Disagree & $23(24.3)$ & $74(74.1)$ & $67(65.6)$ & 164 & & & \\
\hline \multirow{2}{*}{$\begin{array}{l}\text { Thirty percent of secondary } \\
\text { schools have functional infor- } \\
\text { mation and communication } \\
\text { technology facilities }\end{array}$} & Agree & $12(14.4)$ & $49(43.8)$ & $36(38.8)$ & 97 & \multirow[b]{2}{*}{1.953} & \multirow[b]{2}{*}{2} & \multirow[b]{2}{*}{$0.377^{n s}$} \\
\hline & Disagree & $25(22.6)$ & $64(69.2)$ & 64 (61.2) & 153 & & & \\
\hline \multirow{2}{*}{$\begin{array}{l}\text { Eighty percent of tertiary } \\
\text { institutions have functional } \\
\text { information and communication } \\
\text { technology facilities }\end{array}$} & Agree & $21(16.6)$ & $44(50.6)$ & $47(44.8)$ & 112 & \multirow[b]{2}{*}{3.905} & \multirow[b]{2}{*}{2} & \multirow[b]{2}{*}{$0.142^{n s}$} \\
\hline & Disagree & $16(20.4)$ & $69(62.4)$ & $53(55.2)$ & 138 & & & \\
\hline \multirow{2}{*}{$\begin{array}{l}\text { Fifty percent of teachers at all } \\
\text { levels are trained in computer } \\
\text { skills }\end{array}$} & Agree & $16(16.7)$ & $45(51.1)$ & $52(45.2)$ & 113 & \multirow{2}{*}{3.243} & \multirow{2}{*}{2} & \multirow{2}{*}{$0.198^{n s}$} \\
\hline & Disagree & $21(20.3)$ & $68(61.9)$ & $48(54.8)$ & 137 & & & \\
\hline \multirow{2}{*}{$\begin{array}{l}\text { Overall responses to contents } \\
\text { pertaining to an improved } \\
\text { level of ICT capabilities among } \\
\text { students, their teachers and } \\
\text { university lecturers }\end{array}$} & Agree & $14(13.6)$ & $41(41.6)$ & $36(36.8)$ & 92 & & & \\
\hline & Disagree & $23(23.4)$ & $72(71.4)$ & 64 (63.2) & 158 & 0.783 & 2 & $0.676^{n s}$ \\
\hline TOTAL (N) & & 37 & 113 & 100 & 250 & & & \\
\hline
\end{tabular}

Note. $p \geq 0.05$ (ns, not significant). The expected frequencies appear in parentheses beside agree and disagree responses.

\section{Discussion}

Tables 2 and 3 show that lecturers' gender and age group responses who disagreed on the attainment of each of the targets of goal 1 were more than those who agreed. Except for targets 2 and 3 where the responses were more favourable, having an attainment of about 50 percent of junior school students who proceeded to senior secondary school, and 20 percent of senior secondary school graduates who have proceeded to tertiary institutions. The overall responses to goal 1 further revealed that pupils/students of all school levels do not still have unfettered access to functional education for their development.

Globally, the 2013 MDGs Report presents similar results. There are still about 57 million children of primary school age, including 31 million girls, who are not in school due to financial, social or physical challenges. In addition, wide disparities among regions and within countries remain to be addressed in the education agenda (UNESCO, 2013). In 2010, the global 
Isaac Olakanmi ABIMBOLA, Esther Ore OMOSEWO, Johnson Enero UPAHI. Assessment of Education Policy Thrust of the National Economic Empowerment and Development Strategy (Needs) in Nigeria

OBLEMS

OF EDUCATION

IN THE $21^{\text {st }}$ CENTURY

Volume 60, 2014

primary completion rate was about 90 percent and 70 percent in sub-Saharan Africa (UNESCO, 2012a).

Agreed responses to targets $1-4$ of goal 2 were more than the disagreed responses with respect to lecturers' gender and age group, except for target 3 where more female lecturers disagreed that 80 percent of teachers/lecturers in tertiary institutions have already acquired necessary pedagogical skills. The overall agreed responses of lecturers to the attainment of the targets of goal 2 of about $42.4 \%$, as reflected in Tables 4 and 5 further revealed that, the improvement of the quality of education at all levels is still below average. However, there is considerable improvement in the qualifications of teachers at all levels of education. In an MDGs report, a similar result shows that pupil-teacher ratios at the primary level improved globally between 1999 and 2010, especially in East Asia and Latin America. But they worsened in sub-Saharan Africa and South and West Asia. Of 100 countries with data at the primary level, in 33 less than $75 \%$ of teachers were trained to the national standard. Even those who have received training are not always well prepared to teach in the early grades (UNESCO, 2012a).

The overall responses of lecturers with respect to the targets of goal 3 as reflected in Tables 6 and 7 revealed that, students at all levels still have not acquired necessary vocational, technical and entrepreneurial skills to create jobs for themselves so as to live meaningfully within the society, thus, reducing the level of poverty. In other to underscore this finding, similar results revealed that, in many countries children leave school without having developed literacy and numeracy or other relevant skills (UNESCO, 2012c). Consequently, millions of children and youth will still be unable to advance to higher levels of education or to move on to gainful employment.

Tables 8 and 9 shows lecturers' gender and age group responses to the targets of goal 4 , which pertains to periodic review and effective implementation of the secondary school curriculum to meet the requirement of higher education and the world of work. The Tables further revealed that, even though there were curricular revisions, these revisions have not yet reflected the dynamism of the society and the emerging global issues. The Tables further revealed that targets 2 and 4 are considerably being attained.

Tables 10 and 11 shows that, while lecturers' gender and age group responses do not vary significantly on targets pertaining to an improved partnership among private sectors and local communities with respect to support and fund, the $75.6 \%$ disagreed responses from lecturers as compared to the $24.4 \%$ responses, revealed that there is yet a wide gap in the partnership among private sectors and local communities to support and fund education.

Tables 12 and 13 shows lecturers' gender and age group responses on the level of ICT capabilities among students, their teachers and university lecturers. In Table 12, target 6 revealed that there were more female lecturers who agreed that about 80 percent of tertiary institutions already have functional ICT facilities. This response justifies the recent introduction of e-learning systems within our universities, which is gradually positively transforming teaching and learning processes.

Education, which it is hoped to empower the citizens, has witnessed increase in educational institutions both at the primary, secondary and tertiary levels. The Nigerian university system now has 129 universities comprising 51 Private and 40 Federal and 38 State universities, with greater private sector participation (National Universities Commission, 2012). However, the cost of education where average private university charges fees as high as five hundred thousand per session, puts a limit to the number and class of citizens that can have access to such education in a country where over $70 \%$ of the citizens are poor. 


\section{Conclusions}

The NEEDS document produced by the National Planning Commission (2005) made a number of claims that it is the people's plan for prosperity. It coordinates action at the federal and state levels, and it is a feasible plan. But at the time when NEEDS Phase I terminated in 2007, there was not enough to show in terms of targeted achievements. For example, the document claimed that, providing more and more reliable power could triple the volume of production in Nigerian Industries by June, 2007, but the power sector has recorded only slight improvement. The document also stated that future prosperity depends on producing children who are well prepared to take their place in tomorrow's global society, but the education sector has recorded only minimal improvements since the start of NEEDS, hence the need for necessary adjustment. NEEDS phase II commenced in June, 2007 with the expectation of spearheading Nigeria's industrialization. Akintunde and Ojiabor (2006) in Ogundele, et al (2011) reported that the implementation of NEEDS Phase II would build on the achievements of NEEDS Phase I, which started in 2004. Under NEEDS Phase II, it was stated that there would be a focus on employment generation and aggressive public infrastructural development. As at 2010 the objectives of NEEDS phase II, which, among others, is to establish Nigeria as one of the largest industrialized nations, has not been achieved.

The National Economic Empowerment and Development Strategy as a development plan has not really done better, especially in the actual implementation of the education policy thrust. The four key objectives (employment generation, poverty reduction, wealth creation and value reorientation), which recognized education as the vital transformational tool and a formidable instrument for socioeconomic empowerment are indeed attractive issues to be the crux of any worthwhile development plan. But their achievement in the medium terms from 20032007, and a decade after, since inception remains wishful thinking. It is only through committed leadership, continuity with NEEDS document; drawing adequate scale of preference in choosing policies and programmes can NEEDS ever hope to achieve the goals of the education policy thrust, and in general, the objectives of its development plans which hinges on education.

\section{Recommendations}

The government at all levels should spearhead the suggested collaborative effort among stakeholders, particularly the private sector and the local communities, in mobilizing resources to improve support and fund for education.

NEEDS planners and operators should set specific, realizable targets and time framework of human development for students to become self-sufficient in the areas of basic needs through skill acquisition and job creation.

The periodic review of the senior school curriculum should have a strong overt 'application-led' orientation in its review. The curriculum should be sufficient enough to meet the needs of the learners, and should be a sound reflection of societal needs (Mbajiorgu \& Reid, 2006). The curriculum should be such that will equip the students with those skills which will enable them to contribute significantly to the society within and other societies. These skills should be seen in cognitive terms of conceptual understanding, logical and critical thought, creativity, objectivity as well as in generic terms like team working, written and verbal communication.

Although trained and motivated teachers, for example, are essential for improving education quality, not enough attention has been given to ensuring an adequate supply of teachers. To provide quality primary education for all, 114 countries will need at least 1.7 million more teachers in classrooms by 2015 than there were in 2010. More than half of the additional teachers - 993,000 - are needed in sub-Saharan Africa. Other regions in need of additional teachers 
Isaac Olakanmi ABIMBOLA, Esther Ore OMOSEWO, Johnson Enero UPAHI. Assessment of Education Policy Thrust of the National Economic Empowerment and Development Strategy (Needs) in Nigeria

EMS

OF EDUCATION

IN THE $21^{\text {st }}$ CENTURY

Volume 60, 2014

are the Arab States $(248,000)$, South and West Asia $(114,000)$, and North America and Western Europe $(174,000)$ (UNESCO, 2012a)

Teachers are the key factor for the potential success of any educational reform. Most reforms should be initiated from the grassroots, bottom-up, particularly by teachers who are on the field and know what and where a change is needed (Omosewo, 2008). Curriculum emerging through this process will be more acceptable. The issue of teachers' reluctance in implementation will not arise. Appropriate structure must be put in place for teachers' continuing professional development so as to enhance their productivity and make them accountable for quality education (Oloruntegbe, 2011). To successfully implement any reviewed curriculum, governments at all levels, teacher education institutions and teachers' professional associations should collaborate with the aim of providing teachers' opportunities to constantly up-date their knowledge and skills through different innovative approaches (Olorundare \& Upahi, 2013).

Another important recommendation that will lead to realizing the objectives of the NEEDS in the shortest time possible, should the present administration consider the strategy worthwhile, is the importance of doing the first things first. Most developing countries, including Nigeria are too desirous of development, that they believe it can be achieved within a twinkling of an eye. Hence, so many things including things that ought to come later are done at the same time or even earlier than programmes that ought to come later. Therefore, there is the need for the initial sensitization about the development plan, trial testing and evaluation, before institutionalizing framework for the implementation of the NEEDS, and other future development plans.

\section{References}

Abimbola, I. O. (2013). The misunderstood word in science: Towards a technology of perfect understanding for all. The one hundred and twenty-third Inaugural Lecture presented at the University of Ilorin, Ilorin, Nigeria.

Adedokun, M. O. (2011). Literacy: A potent tool for women empowerment. International Journal Review of Social Sciences and Humanities, 1 (2), 13 - 21.

Akintunde, O. \& Ojiabor, O. (2006, October 13). NEEDS II to spearhead Nigeria's industrialization. The Punch. p. 26.

Anugwom, E. E. (2009). Women, education and work in Nigeria. Educational Research and Review Journal, (4), 127-134. Retrieved August 4th, 2013 from http://www.academicjournals.org/ERR

Bamiduro, J. A., \& Babatunde, S. T. (2009). Prospects and challenges for Nigerian industrial and socioeconomic emancipation: Another look at NEEDS.

Imogie, A. I. (2002). Counselling for quality assurance in education. A keynote address at the 26th Annual Conference of Counselling of Nigeria held in the University of Benin: August, 2002.

Mbajiorgu, N., \& Reid, N. (2006). Factors influencing curriculum development in chemistry: A physical sciences practice guide, Hull, United Kingdom: Higher Education Academy of Physical Sciences Centre.

National Planning Commission. (2005). National economic empowerment and development strategy, (NEEDS). Abuja. Central Bank of Nigeria.

National Universities Commission (2012). FEC approves 5 new private universities. Retrieved from www.Resourcedat.com.ng/resources/list-of-Approved-Universities.pdf

Ogundele, O. J. K., Hassan, A. S., \& Abdulazeez, I. A. (2011). Projecting the possible impacts of the national economic empowerment and development strategy (NEEDS) on human development in Nigeria, International Journal of Economics and Finance, 3 (4), 1 - 8.

Olorundare, A. S., \& Upahi, J. E. (2013). Global Best Practices in the Teaching and Learning of Science, An Official Journal of the Collaboration of Education Faculties in West Africa, 2 (1), 54 - 68.

Oloruntegbe, K. O. (2011). Teachers' involvement, commitment and innovativeness in curriculum development and implementation. Journal of Emerging Trends in Educational Research and Policy Studies (JETERAPS), 2 (6), 443-449. 
Omosewo E. O. (2008). Physics teacher education and national education reform. In Adebayo, R. Lawal et al. Education Reforms in Nigeria Past, Present and Future, pp. 246-250, Adebayo, R. Lawal, Shehu A. Jimoh, Solomon A. Olorundare \& Nike Y. S. Ijaiya (Eds.). A book published by the Faculty of Education, University of Ilorin, Ilorin, Nigeria.

UNDP. (2010). Human Development Report Nigeria 2008-2009. Achieving Growth with Equity. UNDP.

UNESCO. (2013b) Education for All Global Monitoring Report: Schooling for millions of children jeopardized by reductions in aid. Policy Paper 9 available from http://unesdoc.unesco.org/ images/0022/002211/221129E.pdf

UNESCO. (2012b). The Millennium Development Goals Report 2012. New York. Available from www. un.org/millenniumgoals/pdf/MDG\%20Report\%202012.pdf

UNESCO Institute for Statistics. (2012a). Opportunities lost: the impact of grade repetition and early school leaving. Global Education Digest 2012. Montreal. Available from http://www.unesco.org/ new/en/education/resources/online-materials/singleview/news/global_education_digest_2012_ opportunities_lost_the_impact_of_grade_repetition_and_early_school_leaving

UNESCO \& UNICEF. (2013). Making education a priority in the Post-2015 development agenda: Report of the global thematic consultation on education in the Post-2015 development agenda. Available from www.worldwewant2015.org/file/389575/download/423267

Advised by Muammer Calik, Karadeniz Technical University, Turkey

Received: January 15, 2014

Accepted: March 08, 2014

\begin{tabular}{l} 
PROBLEMS \\
OF EDUCATION \\
IN THE $21^{\text {st }}$ CENTURY \\
Volume 60, 2014 \\
\hline 45
\end{tabular}

Isaac Olakanmi Abimbola

PhD., Professor, Department of Science Education,

Faculty of Education, University of Ilorin, P. M. B. 1515, Ilorin, Nigeria.

E-mail: abimbola@unilorin.edu.ng

Esther Ore Omosewo

PhD., Professor, University of Ilorin, P. M. B. 1515, Ilorin, Nigeria.

E-mail: oresewo@yahoo.co.uk

Johnson Enero Upahi

Assistant Lecturer, University of Ilorin, Ilorin, Nigeria

E-mail: johnsonenero@yahoo.com 